\title{
Studies on mosquitoes (Diptera: Culicidae) and anthropic environment. 7- Behaviour of adults Nyssorhynchus anophelines with special reference to Anopheles albitarsis s.l. in South-Eastern Brazil ${ }^{\star}$
}

\author{
Oswaldo Paulo Forattini, Iná Kakitani, Eduardo Massad, \\ Daniel Marucci
}

\author{
Department of Epidemiology, School of Public Health, University of S. Paulo. \\ Taxonomic and Systematic Research in Medical Entomology Unit of the \\ University of S. Paulo (NUPTEM) - Brazil (O.P.F., I.K., D.M.); Department of \\ Pathology, School of Medicine, University of S. Paulo-Brazil (E.M.)
}

\begin{abstract}
Results obtained with catches performed at several sites of the Ribeira Valley, SP (Brazil) are reported. Collections with Shannon type traps showed a concentration of An.albitarsis s.l, in the Experimental Farm of Pariquera-Acu County, associated with the development of irrigated rice cultivation. Two species of the complex, named $A$ and $B$, were recognized. Species B predominated in the samples. Indoor and outdoor crepuscular human balt captures were performed a the domiciliary environment. The two species showed a generaliy low Willam's media valve of 0.2 , the highest value obtained was 1.6. No differences were found between indoor and outdoor behavlours between the two species of the complex.
\end{abstract}

Anopheles. Ecology, vectors. Malaria, transmition.

\section{Introduction}

The Ribeira Valley region of S. Paulo State (Brazil) currently presents malaria at a hypoendemic level. Among the factors that may contribute to its ressurgence is the impact of agricultural irrigation practices that may increase adult mosquito populations. As previously mentioned, the implementation of rice cultivation techniques at the Experimental Farm in "Pariquera-Açu" County resulted in the increase of Anopheles albitarsis s.1. This species is a potential malaria vector and an efficient colonizer of areas occupied by humans, with habits that may be classified as eusynanthropic (Rosa-Freitas ${ }^{20}, 1990$; Forattini et al. ${ }^{10}, 1993$ ).

This is part of a survey of the regional ground water breeding anophelines, with special emphasis to biting behavior. The present paper presents data on the Subgenus Nyssorhynchus species, comparing different populations in the region, with those found in the irrigated rice farm, with special reference to An. albitarsis s.l.

\section{Study Areas}

Adult collections were performed at an Experimental Station (ES) described in Forattini et al." 10, " $(1993,1994)$. Outdoor and indoor adult collections were carried out at ES area in rural dwellings of the "Sítio Barra do Capinzal" (BC) (Forattini et al.", 1993), a site nearly one kilometer, in a straight line, away from the rice paddies. For purposes of comparison, collections

* Supported by "Fundaçāo de Amparo à Pesquisa do Estado de Sao Paulo (FAPESP)" (Grant no. 90/337I-6).

Reprints: Oswaldo Paulo Forattini - Department of Epidemiology, School of Public Health, University of S. Paulo. Taxonomic and Systematic Research in Medical Entomology Unit of the University of S, Paulo (NUPTEM) - Av. Dr. Arnaldo, 7I5 - 01246-904 - S. Paulo, SP - Brazil.

The publication of this article was supported by FAPESP (Process 94/0500-0).

Submited in 11.24.1994. Approved in 12.14.1994. 
were made also at an area known as "Sítio Galiléia" (GA). It is an example of another human settlement showing considerable environmental modification, but without artificial irrigation systems nor intensive agricultural activities. It is located in the "Pariquera-Açu" County, nearly 30 kilometers away from the municipality seat. Catches here were performed at the margin of the upper part of the "Pariquera-Açu" river.

\section{Matherial and Method}

Adult mosquitoes were sampled at fortnightly regular intervals and, as a routine, captures were made from 17:00 to 20:00 hours. Shannon type light traps were used, operated by two men team. Collection periods were as follow:

1) February through December 1993:

Shan- 1 inside forest remnant $A$ at ES.

Shan-2 inside forest remnant B at ES.

Shan-E in open land at the rice paddy margin atES.

The operation of Shan-1 and Shan-2 were alternated so that the total number of specimen caught corresponded to the fortnightly collections rhythm.

2) August 1992 through December 1993:

Shan-GA at the margin of upper PariqueraAçu river.

In addition to sample mosquito populations near human habitations, human bait captures were used. The collectors caugth females as they came to feed on their exposed legs. Simultaneous, indoor and outdoor collections were made, using battery-opperated aspirators during two hours that included the evening crepuscular period. Indoor captures were made inside human dwellings and the outdoor ones made nearby. A regular fortnightly rhythm was followed, from August 1992 through December 1993, at the "Sítio Barra do Capinzal" (BC) bordering ES. Biting activity was estimated through the Williams media $\left(\mathrm{X}_{\mathrm{w}}\right)$ as originally used by Haddow ${ }^{12,13}(1954,1960)$.

According to R. C. Wilkerson", there are four species now known in the An. albitarsis complex. At the ES (referred by him as "Registro"), there are two species that may be separated through the dark part of the second posterior tarsomere (TA-III ${ }_{2}$ ) presectorial with

* Personal communication (May 1994).

dark spot (PSD), as follow:

Species A - TA-III $25 \%$ or less basal dark. Species B - TA-III, more than $50 \%$ basal dark.

Besides, the wing presectorial dark spot (PSD) character is used by that author and according to him PSD is absent or short $(<0.09$ length of wing) in species $A$, whereas PSD is longer $(0.05-0.14$ length of wing $)$ in species $B$. Even if this character was not used in the present research, according to R. C. Wilkerson * the combination of these two characters used on a sample of specimens from this site, verified by RAPD-PCR analysis, resulted in no misidentifications. Because of overlap of measurements those characters are not effective if other species in the complex are also present.

\section{Results}

A total of 22,039 adult females mosquitoes belonging to Anopheles (Nyssorhynchus) species were collected. From those 21,761 (98.7\%) were caught at the Experimental Station area, including Shannon trap and human bait collections. The GA collections provided 278 (1.3\%) mosquitoes of the total caught. The species from both sites were distributed as follow:

$\begin{array}{lcc}\text { Species } & \mathrm{N} & \% \\ \text { An. albitarsis A } & 1,126 & 5.1 \\ \text { An. albitarsis B } & 20,337 & 92.3 \\ \text { An. evansae } & 55 & 0.2 \\ \text { An. galvaoi } & 81 & 0.4 \\ \text { An. futzii } & 125 & 0.6 \\ \text { An. oswaldoi } & 48 & 0.2 \\ \text { An. parvus } & 59 & 0.3 \\ \text { An. strodei } & 184 & 0.8 \\ \text { An. triannulatus } & 24 & 0.1 \\ \text { Total } & 22,039 & 100.0\end{array}$

Of these, $97.3 \%$ were Anopheles albitarsis complex. The other species were not found in significant numbers, as be seen below:

Species

An. albitarsis s.I.

An. evansae

An. galvaol

An. ivtzii

An. oswaldol

An. parvus

An. strodei

An. triannulatus

Total

\begin{tabular}{c} 
Experimen \\
Station (E \\
21,462 \\
46 \\
73 \\
- \\
30 \\
- \\
127 \\
23 \\
\hline 21,761
\end{tabular}

Sitio Galiléia (GA)

\begin{tabular}{c}
1 \\
9 \\
8 \\
125 \\
18 \\
59 \\
57 \\
1 \\
\hline 278
\end{tabular}




\section{Anopheles Albitarsis s.l.}

Only one specimen of An. albitarsis s.1. was found outside the Experimental Station (ES) area at "Sítio Galiléia". According to R. C. Wilkerson's* criteria it was identified as species B. Therefore, practically all the material of the An albitarsis complex studied here was captured at ES.

Shannon traps- The monthly distribution of An. albitarsis species A and B is presented in Table. Few specimens were taken at Shan2 (four An. evansae and three An. oswaldoi) and no An.albitarsis complex. A total of 21,237 females were collected with species B clearly predominating with $94.7 \%$ versus $5.3 \%$ for species A. Besides, species A was found only on the open land (Shan E) being absent of the catches performed in the other ES remnant wood (Shan-1).

Considering the monthly percentages

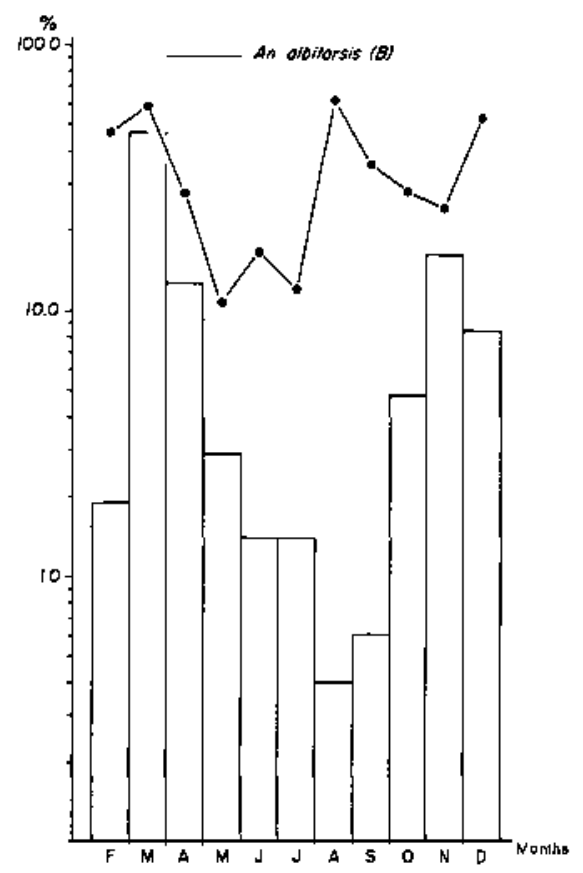

Figure 1. Distribution of An.albitarsis species B rates in the monthly catches performed by the employ of Shannon trap operating at the ES open land (Shan-E). Percentages regarding the species $B$ were calculated over the all monthly culicids collected. Bars represents the monthly percentages of the mosquitoes catched over the total number coilected during the observation period (February through December 1993).

* Personal communication (May 1994). related to the all mosquitoes collected by the Shan-E, the distribution of species B is presented by the graphic of the Figure 1 . Apparently it seems that the mosquito distributed in an independent way, being produced even in the months when the others are not at least in an intensive manner. The part of that graphic concerning the June-October period seems to show that.

Regarding the local rice cultivation cycle, as the Shan-E was operated at the paddies margin in the open land, an attempt was made to compare the data obtained with those related to the immature stages and already published (Fig. 2). During the period from August through December the collections of $A n$. albitarsis s.1. yields increasingly adults, starting with the stage 3 of that cycle that corresponds to the permanent flooding start and the seedlings rice transplantation.

Domiciliary environment - Through the use of human bait, a total of 393 females were caught which $66(16.8 \%)$ belonging to species A and $327(83.2 \%)$ to species B. With respect to

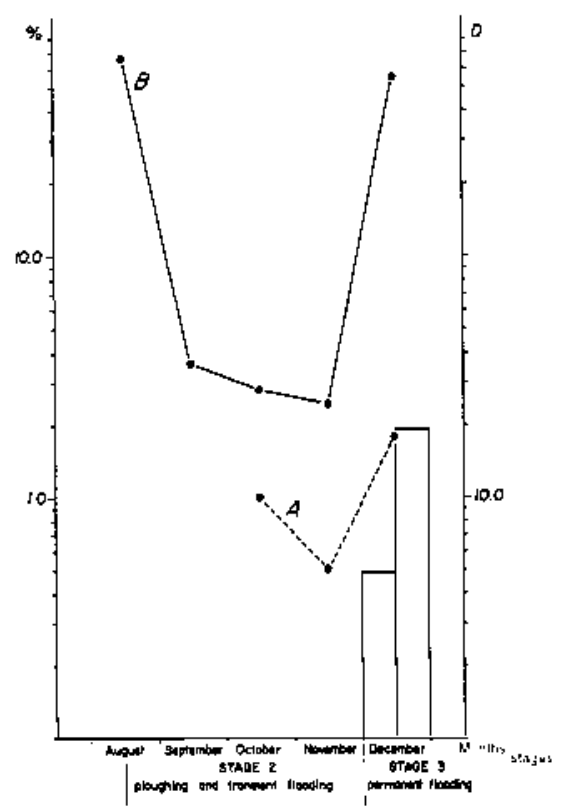

Figure 2. Distribution of An. albitarsis species A and $B$, caught at the ES open land by Shannon trap (Shan-E), during the period from August through December 1993 corresponding to the stage 2 and starting stage 3 of the local rice cultivation cycle. Bars represents the immature forms collected in the paddies (Forattini et al. $\left.{ }^{11}, 1994\right)$. Percentages rates $(\%)$ were calculated on the total number of adult culicids collected belonging to the several species. D- number of immature forms per 10 dips. 
collection site the results were as follow:

\begin{tabular}{lcccc} 
& Indoor & Outdoor & Total \\
An. abbitarsis A & $39(16.0 \%)$ & & $27(18.0 \%)$ & $66(16.8 \%)$ \\
An. albitarsis B & $204(84.0 \%)$ & & $123(82.0 \%)$ & $\frac{327(83.2 \%)}{393}$ \\
\cline { 2 - 3 } Total & 243 & & 150 &
\end{tabular}

No significant differences were found between the two sites sampled $\left(\mathrm{X}^{2}=0.25 . \mathrm{P}=\right.$ 0,6152872 ). Nevertheless, species B was more frequently found than species $A$, both indoors and outdoors. Of the total females, $382(97,2 \%)$ were caught during January-August while 288 $(73,3 \%)$ were caught during January-April period. Therefore, peak abundance corresponds to the time of the majors numbers of these mosquitos collected at the paddies by the Shan$E$ trap February-Aptil months (Table).

The Williams' media $\left(\mathrm{X}_{\mathrm{w}}\right)$ was 0.2 as monthly general value per hour of sampling. The distribution was as follows:

$\begin{array}{lccc}\text { Month 1993 } & \mathrm{n} & \% & \mathrm{X}_{\mathrm{w}} \\ \text { January } & 67 & 17.5 & 1.4 \\ \text { February } & 72 & 18.9 & 1.5 \\ \text { March } & 96 & 25.1 & 1.6 \\ \text { April } & 53 & 13.9 & 1.3 \\ \text { May } & 39 & 10.2 & 1.1 \\ \text { June } & 12 & 3.1 & 0.3 \\ \text { July } & 31 & 8.2 & 1.0 \\ \text { August } & 12 & \mathbf{3 . 1} & 0.6 \\ \text { Total } & \underline{382} & \underline{100.0} & 0.2\end{array}$

During the above mentioned FebruaryApril period, the Williams' media rises to 0.9 .

Concerning others Nyssorhynchus species the results obtained were as follows:

$\begin{array}{lccc} & \text { indoor } & \text { Outdoor } & \text { Total } \\ \text { An. gaivaol } & - & 2 & 2 \\ \text { An. oswaldoi } & 1 & 2 & 3 \\ \text { An. strodei } & 2 & 1 & 3 \\ \text { An. triannulatus } & 1 & \frac{1}{6} & \frac{2}{10} \\ \text { Total } & 4 & \end{array}$

\section{Discussion}

The results obtained with the present study reinforces the already described prevalence of Anopheles albitarsis s.1. at this irrigated site (Forattini et al. $\left.{ }^{10,11}, 1993,1994\right)$. The main objective was to compare the adult abundance at different sites. Two different techniques for sampling were employed; Shannon traps at the rice farming area and human bait. Notwithstanding this one was utilized only for the domiciliary catches while the others were largely used at the several places, chosen for sampling.

As mentioned above, it seems that several species compose the An. albitarsis complex. Preliminary results obtained with the random amplified polymorphic DNA technique suggested a minimum of four genetically distinguishable groups (Wilkerson et al. ${ }^{25}$ ). Two of these species were found at our study site, here named A and B. These were phenotipically distinguished according to Wilkerson's criteria. In general, species B, clearly predominated in the samples obtained (Table).

The Experimental Station (ES) area concentrated all the material here obtained related to An. albitarsis s.l. This aspect sustains the hypothesis about the eusynanthropy of that mosquito and strongly suggests its adaptation to artificial human environment represented by the rice irrigation field. The outdoor collections performed simultaneously at the "Sítio Galiléia" (GA) showed that the mosquito was practically nonexistent there, a pattern that was observed earlier (Forattini et al. ${ }^{6.7}, 1978$ ). Besides the collections at the margins paddies, the mosquito was also found at forest remnant (Shan-1) and, as was already reported, in the open land bordering that patch forest (Forattini et al.", 1981). Consequently, it is suitable to rise hypothesis that the local irrigation development has brought about collateral effects, among them the production and increase of $A n$. albitarsis s.1. populations. This anopheline is found in the whole Ribeira Valley region but generally at very low densities. Therefore, the open areas of the anthropic environment seem to act as a concentration site and the irrigation as the main factor. Mosquitoes belonging to this complex were implicated in malaria transmission in nearby "Iguape" (Schiavi"24, 1945; Forattini', 1962). It is possible therefore that, because of rice farming, this complex could be important in future malaria transmission. The association of this complex with the rice fields is known from previous research (Lacey and Lacey ${ }^{15}, 1990$ ). Its seasonality and increase in numbers related to permanent flooding (stage 3 ) of the rice cultivation cycle is suggested here (Figs. 1 and 2).

Sampling at the domiciliary environment, showed densities with low Williams' media and limited to certain months, particularly the first semester. In addition, there were no concordance with the starting phase of the permanent flooding of the rice fields. However, the results seem to demostrate that the females of An. albitarsis s.l. are atracted by human bait both outdoors and indoors. This behaviour agrees with that observed in several regions as Southern Brazil, Suriname, Colombia, Trinidad and Venezuela (Consolim?, 
Table. Distribution of Anopheles abitarsis s.l. collected in Shannon traps at the Experimental Station (ES) area, February through December 1993.*

\begin{tabular}{|c|c|c|c|c|c|c|c|c|c|c|c|c|c|c|}
\hline \multirow{3}{*}{ Months } & \multirow{3}{*}{$\begin{array}{l}\text { Shannon } \\
\text { Traps }\end{array}$} & \multicolumn{4}{|c|}{ Species A } & \multicolumn{4}{|c|}{ Species B } & \multicolumn{5}{|c|}{ Total } \\
\hline & & \multicolumn{2}{|c|}{ Fenale } & \multicolumn{2}{|c|}{ Male } & \multicolumn{2}{|c|}{ Female } & \multicolumn{2}{|c|}{ Male } & \multicolumn{2}{|c|}{ Female } & \multicolumn{2}{|c|}{ Male } & \multirow[t]{2}{*}{$\bar{T}$} \\
\hline & & $n$ & $\%$ & $n$ & $\%$ & $n$ & $\%$ & $\pi$ & $\%$ & $n$ & $\%$ & $n$ & $\%$ & \\
\hline \multirow[t]{2}{*}{ February } & $E$ & 92 & 8.2 & - & - & 402 & 2.0 & . & - & 494 & 2,3 & . & - & 494 \\
\hline & 1 & - & - & - & - & 43 & 0.2 & - & - & 43 & 0.2 & - & - & 43 \\
\hline \multirow[t]{2}{*}{ March } & E & 757 & 67.4 & 2 & $\ldots$ & 13,174 & 65.2 & 75 & 51.0 & 13,931 & 65.4 & $\pi$ & 51.3 & 14,008 \\
\hline & 1 & - & $\cdot$ & - & • & 29 & 0.1 & 2 & 1.4 & 29 & 0.1 & 2 & 1.3 & 31 \\
\hline \multirow[t]{2}{*}{ April } & $E$ & 99 & 8.8 & 1 & $\ldots$ & 1,607 & B. 0 & 22 & 15.0 & 1,706 & 8.0 & 23 & 15.3 & 1,729 \\
\hline & 1 & - & - & - & - & 2 & $\ldots$ & . & . & 2 & $\ldots$ & • & . & 2 \\
\hline \multirow[t]{2}{*}{ May } & E & 33 & 2.9 & $\cdot$ & $\cdot$ & 143 & 0.7 & - & $\cdot$ & 176 & 0.8 & - & - & 176 \\
\hline & 1 & . & . & $\cdot$ & . & - & - & - & $\cdot$ & . & $\cdot$ & - & - & - \\
\hline \multirow{2}{*}{ June } & E & 7 & 0.6 & - & . & 104 & 0.5 & - & - & 111 & 0.5 & - & - & 111 \\
\hline & 1 & - & - & . & $\cdot$ & - & - & - & - & - & - & - & - & - \\
\hline \multirow[t]{2}{*}{ July } & $E$ & 6 & 0.5 & - & $\cdot$ & 74 & 0.4 & - & - & 80 & 0.4 & - & - & 80 \\
\hline & 1 & . & . & . & - & - & - & - & - & - & - & - & - & - \\
\hline \multirow[t]{2}{*}{ August } & $E$ & - & . & - & - & 112 & 0.6 & a & 5.4 & 112 & 0.5 & 8 & 5.3 & 120 \\
\hline & 1 & - & - & - & - & 1 & ... & - & - & 1 & $\ldots$ & - & - & 1 \\
\hline \multirow[t]{2}{*}{ September } & $E$ & - & - & $\cdot$ & - & 97 & 0.5 & - & $\cdot$ & 97 & 0.4 & - & - & 97 \\
\hline & 1 & - & - & . & - & - & - & - & - & - & - & - & - & - \\
\hline \multirow[t]{2}{*}{ October } & $E$ & 22 & 2.0 & - & . & 604 & 3.0 & 14 & 9.5 & 626 & 2.9 & 14 & 9.3 & 640 \\
\hline & 1 & - & - & . & . & $\cdot$ & - & $\cdot$ & - & $\cdot$ & • & - & - & • \\
\hline \multirow[t]{2}{*}{ November } & $E$ & 40 & 3.6 & $\cdot$ & $\cdot$ & 1,791 & 8.9 & 17 & 11.6 & 1,831 & 8.6 & 17 & 11.3 & 1,848 \\
\hline & 1 & • & - & $\cdot$ & $\cdot$ & - & - & - & - & - & - & - & - & - \\
\hline \multirow[t]{2}{*}{ December } & $E$ & 67 & 6.0 & $\cdot$ & · & 2,006 & 9.9 & 9 & 6.1 & 2,073 & 9.7 & 9 & 6.0 & 2,082 \\
\hline & 1 & $\cdot$ & - & $\cdot$ & $\therefore$ & $\cdot$ & $\cdot$ & $\cdot$ & - & - & $\cdot$ & - & - & - \\
\hline \multirow[t]{3}{*}{ Total } & $E$ & 1,123 & 100.0 & 3 & $\ldots$ & 20,114 & 99.6 & 145 & 98.6 & 21,237 & 99.6 & 148 & 98.7 & 21,385 \\
\hline & 1 & - & - & - & - & 75 & 0.4 & 2 & 1.4 & 75 & 0.3 & 2 & 1.3 & 77 \\
\hline & $T$ & 1,123 & 100.0 & 3 & $\ldots$ & 20,189 & 100.0 & 147 & 100.0 & 21,312 & 99.9 & 150 & 100.0 & 21,462 \\
\hline
\end{tabular}

* Species A and B distinguished according to Wilkerson's criteria (personal communication - May, 1994).

1974; Kuyp and Baboeram ${ }^{14}, 1985$; Quiñones et al. ${ }^{16}, 1992$; Chadee $^{2}$, 1992; Rubio-Palis and Curtis ${ }^{22}$, 1992). Nevertheless, bait preference may vary geographically (Deane et al. ${ }^{4}, 1988$ ). As was mentioned above, in the present study no concordance was observed between the domiciliary environmental catches and those performed at the ES paddies margin (Shan-E) during the starting phase of the rice field permanent flooding corresponding to November and December 1993. In the period including September until December of that year only nine specimens (six outdoors and three indoors) of species B, were caught in the domiciliary environment. This result contrasted with that obtained with the ShanE trap (Table). No suitable explanation was found until now but perhaps the different sampling techniques have something to do with it. Regarding the other Nyssorhynchus species, the data obtained were scarce and therefore inconclusive.

In conclusion, it seems clear that irrigation for rice farming in the Ribeira Valley region may increase the populational density of several mosquitoes. Among them, Anopheles albitarsis s.l. deserves particular attention since it is regarded as malaria vector its competence has been reported in several South American sites (Arruda et al.', 1986; Oliveira-Ferreira et al. ${ }^{19}, 1990$; Rubio-Palis $^{21}$, 1992; Rubio-Palis et al, ${ }^{23}, 1992$ ), Even thought usually considered as a secondary vector, in the past it was shown to be a primary vector in the Iguape area of the Ribeira Valley region. Besides this, its competence for arbovirus transmission also has been reported (Mitchell et al. ${ }^{17,18}, 1985$, 1987). So it is justifiable to pay attention to human activities that may favour large populations of this anopheline mosquito complex.

\section{Aknowledgment}

To Dr. Richard C. Wilkerson for their valuable suggestions that were included in this paper.

\section{References}

1. ARRUDA, M. de; CARVALHO, M.B.; NUSSENZWEIG, R.S.; MARACIC, M.; FERREIRA, A.W.; COCHRANE, A.H. Potential vectors of malaria and their different suscetibility to Plasmodium falciparum and Plasmodium vivax in northern Brazil identified by 
immunoassay. Am.J.Trop.Med.Hyg., 35:873-81, 1986.

2. CHADEE, D.D. Indoor and outdoor host-seeking rhythms of Anopheles albitarsis (Diptera: Culicidae) in Trinidad, West Indies. J.Med.Entomol., 29:567-9, 1992.

3. CONSOLIN, J. Sobre os anofelinos do Rio Paraná. IIComportamento do inseto en relaçăo ao homem e a habitação. Arq.Biol.Tecnol, 17:24-9, 1974.

4. DEANE, L.M.; RIBEIRO, C.D.; LOURENÇO DE OLIVEIRA, R.; OLIVEIRA-FERREIRA, J.A.; GUIMARĀES, E. Study on the natural history of malaria in areas of the Rondonia State-Brazil and problems related to its control. Rev.Inst.Med.Trop.S. Punlo, 30:153-6, 1988

5. FORATTINI, O.P. Emomolagia médica, São Paulo, Fac. Higiene e Saúde Pública da USP, 1962.

6. FORATTINI, O.P.; GOMES, A.de C.; GALATI, E.A.B.; RABELLO, E.X.; IVERSSON, L.B. Estudos ecológicos sobre mosquitos Culicidae no sistema da Serra do Mar, Brasil. 1- Observaçōes no ambiente extradomiciliar. Rev.Saude Pública, 12:297-325, 1978.

7. FORATTINI, O.P.; GOMES, A.de C.; GALATI, E.A.B.; RABELLO, E.X.; IVERSSON, L.B. Estudos ecológicos sobre mosquitos Culicidae no sistema da Serra do Mar, Brasil. 2- Observaçōes no ambiente domiciliar. Rev. Saude Pública, 12:476-96, 1978.

8. FORATTINI, O.P.; GOMES, A.de C.: SANTOS, J.L.F.; GALATI, E.A.B.: RABELLO, E.X.; NATAL, D. Observaç̧es sobre atividade de mosquitos Culicidae em mata residual to Vale do Ribeira, S.Paulo, Brasil. Rev.Sáde Pública, 15:557-86, 1981.

9. FORATTINI,O.P.; KAKITANI,I.;MASSAD,E.; MARUCCl, D. Studies on mosquitoes (Diptera: Culicidae) and anthropic environment. 2 - Immature stages research at a rice irrigation system location in South-Eastern Brazil. Rev. Saúde Pública, 27:227-36, 1993.

10.FORATTINI, O.P.: KAKITANI, I.; MASSAD, E.; MARUCCI, D. Studies on mosquitoes (Diptera: Culicidae) and anthropic environment. 3 - Survey of adult stages at the rice irrigation system and the emergence of Anopheles albitar.sis in South-Eastern Brazil. Rev. Saide Pública, 27:313-25, 1993.

11.FORATTINI, O.P.; KAKITANI, I.; MASSAD, E.; MARUCCI, D. Studies on mosquitoes (Diptera: Culicidae) and anthropic environment. 5 - Breeding of Anopheles albitarsis in flooded rice fields in SouthEastern Brazil, Rev. Saúde Pública, 28:329-31، 1994.

12.HADDOW, A.J. Studies on the biting-habits of african mosquitoes and appraisal of methods employed, with special reference to the twenty-four-hour catch. Bull.Entomol.Res., 45; 199-242, 1954.

13.HADDOW, A.J. Studies on the biting habits and medical importance of east African mosquitoes in the genus Aedes. 1- Subgenera Aedimorphus, Banksinella and Dunnius. Bull ent.Res., 50:759-79, 1960.
14.KUYP, E, van der \& BABOERAM, A. Mosquitoes in and around Wageningen, Nickerie District, Suriname. Sur.Med.Bull, 9:108-15, 1985.

15.LACEY, L.A. \& LACEY, C.M. The medical importance of riceland mosquitoes and their control using alternatives to chemical insecticides. J.Am.Mosq. Control Assoc., 6(Suppl.2):1-93, 1990.

16.QUIÑONES, M.C.; VILLAREAL, L.I.; SUAREZ, M.F. Distribution and biting behavior of Anopheles species in Casanare, Colombia. J.Am.Mosq.Control Assoc., 8:305-6, 1992

17.MITCHELL, C.J.; MONATH, T.P.; SABATTINI, M.S.; CROPP, C.B.; DAFFNER, J.F.; CALISHER, C.H.; JAKOB, W.L.; CHRISTENSEN, H.A. Arbovirus investigations in Argentina, 1977-1980. II. Arthropod collections and virus isolations from argentine mosquitoes. Am.J.Trop.Med.Hyg., 34:945-55, 1985.

18.MJTCHELL, C.J.; MONATH, T. P.; SABATTINI, M.S .; DAFFNER, J.F.; CROPP, C.B.; CALISHER, C.H.; DARSIE, Jr. R.F.; JAKOB, W.L. Arbovirus isolations from mosquitoes collected during and after the 1982-1983 epizootic of Western Equine Encephalitis in Argentina. Am.J.Trop.Med.Hyg. 36:107-13, 1987.

19.OLIVEIRA-FERREIRA,J.;LOURENÇO-DE-OLIVEIRA,R.; TEVA, A.: DEANE, L. M.; DANIEL-RIBEIRO, C. T. Natural malaria infections in Antpheles in Rondonia State, Brazilian Amazon, Am. J. Trop. Med. Hyz., 43:6-10, 1990.

20. ROSA-FREITAS, M.G.; DEANE, L.M.; MOMEN, H.A. A morphological isoenzymatic and behavioural study of ten populations of Anopheles (Nyssorhynchus) albitarsis Lynch-Arribalzaga, 1878 (Diptera: Culicidae) including from the type locality. Baradeso, Argentina. Mem.Inst.Oswaldo Cruz, $85: 275-289,1990$.

21.RUBIO-PALIS, Y. Vectorial capacity of anopheline in westem Venezuela (Capacida vectorial de los anofelinos del occidente de Venezuela). J. Am. Mosq. Conrrol Assoc., 8:307, 1992.

22.RUBIO-PALIS, Y. \& CURTIS, C.F. Biting and resting behaviour of anophelines in western Venezuela and implications for control of malaria transmission. Med. Vet. Entomol., 6:325-34, 1992.

23.RUBIO-PALIS, Y.; WIRTZ, R.A.; CURTIS, C.F. Malaria entomological inoculation rates in western Venezuela. Acta Tropica, 52:167.74, 1992.

24.SCHIAVI, A. Nota sobre mosquitos vetores em Iguape. Arquiv, Hig, Saide Publica, 10:60-72, 1945.

25.WILKERSON, R.C.; PARSONS, T.J.; KLEIN, T.A.; GAFTIGAN, T,V ; BERGO, E.; CONSOLIM, J. Diagnosis by RAPD-PCR of four cryptic species related to Anopheles (Nyssorhynchus) atbitarsis from Paraguay, Argentina and Brazil (Diptera: Culicidae). J.Med.Entomol. [in press]. 


\section{Resumo}

Relatam-se os resultados obtidos com coletas levadas a efeito em areas do Vale do Ribeira, SP (Brasil) e mediante o emprego de armadihas tipo Shannon. As evidencias obtidas mostraram clara associaçăo com o cultivo de arroz irrigado na Fazenda Experimental de Pariquera-Açu. Tudo leva a crer que ali ocorra concentraçăo populacional desse complexo na qual pôde-se diferenciar duas espécies, designadas como A e B. A espécie B predominou francamente em todas as coletas. No ambiente domiciliar foi empregada a isca humana nas coletas efetuadas regularmente no intra e no peridomicilio. Em ambas situaçōes foram encontradas as duas especles, com baixo valor geral da média de Willams correspondente a 0,2 . Considerando-se separadamente os resultados mensais, póde-se obter valor máximo de 1,6 . Nāo foi possivel detectar qualquer diferença entre os dois ambientes, no que concerne à freqüência de ambas as espécies do complexo.

Anopheles. Ecologia de vetores. Malária, Transmissão. 